\title{
Techniques for the In Vitro Production of Queens in Stingless Bees (Apidae, Meliponini)
}

\author{
by \\ Ana Rita Baptistella ${ }^{1}$, Camila C. M. Souza ${ }^{2}$, Weyder Cristiano Santana ${ }^{3 *}$ \\ $\&$ Ademilson Espencer Egea Soares ${ }^{2}$
}

\begin{abstract}
Considering the ecological importance of stingless bees as caretakers and pollinators of a variety of native plants makes it necessary to improve techniques which increase of colonies' number in order to preserve these species and the biodiversity associated with them. Thus, our aim was to develop a methodology of in vitro production of stingless bee queens by offering a large quantity of food to the larvae. Our methodology consisted of determining the amount of larval food needed for the development of the queens, collecting and storing the larval food, and feeding the food to the larvae in acrylic plates. We found that the total average amount of larval food in a worker bee cell of $F$. varia is approximately $26.70 \pm 3.55 \mu \mathrm{L}$. We observed that after the consumption of extra amounts of food $(25,30,35$ and $40 \mu \mathrm{L})$ the larvae differentiate into queens $(n=98)$. Therefore, the average total volume of food needed for the differentiation of a young larva of $F$. varia queen is approximately $61.70 \pm 5.00 \mu \mathrm{L}$. In other words; the larvae destined to become queens eat 2.31 times more food than the ones destined to become workers. We used the species Frieseomelitta varia as a model, however the methodology can be reproduced for all species of stingless bees whose mechanism of caste differentiation depends on the amount of food ingested by the larvae. Our results demonstrate the effectiveness of the in vitro technique developed herein, pointing to the possibility of its use as a tool to assist the production of

\footnotetext{
${ }^{1}$ Biology Department, Laboratory of bee Biology and Genetics, Faculty of Philosophy, Sciences and Letters of Ribeirão Preto, University of São Paulo, Brazil.

${ }^{2}$ Genetic Department, Laboratory of bee Biology and Genetics, Medicine Faculty of Ribeirão Preto, University of São Paulo, Brazil.

${ }^{3}$ Entomology Department, Federal University of Viçosa, Brazil.

${ }^{*}$ Correspondence author: Weyder Cristiano Santana, Entomology Department, Federal University of Viçosa, PH Rolfs Avenue, s/n, Zip Code: 36571-000, Viçosa, Minas Gerais, Brazil. e-mail:weyder.santana@ufv.br
} 
queens on a large scale. This would allow for the artificial splitting of colonies and contribute to conservation efforts in native bees.

Key Words: stingless bees; production of queens; caste determination; Frieseomelitta varia; larval food; colony splitting.

\section{INTRODUCTION}

Stingless bees (Apidae, Meliponini) are very common in the tropics and are the main pollinators of tropical ecosystems (Roubik 1984; Corlett 2004). It is believed that about 40 to $90 \%$ of native trees in Brazil are pollinated by these bees (Kerr et al. 1996). Thus, the need to preserve the species of native bees lies mainly in the broad action of these agents as pollinators of our flora, ensuring the conservation of the fauna and all its associated biodiversity.

One of the most striking features of the biology of stingless bees, besides that of beinghighly eusocial and a sister group of Apismellifera (Apidae, Apini) (Michener 2000), is related to the larvae's feeding process, which presents a strategy of mass food supply in their brood cells (Kerr 1948; Nogueira-Neto 1997; Michener 2000).

The mechanism of caste determination differs between the bees of the genus Melipona and the bees from other genres of this tribe (Kerr 1950; Kerr \& Laidlaw 1956; Maciel-Silva \& Kerr 1991; Hartfelder et al. 2006). The caste induction in most of the stingless bees is related to the amount of food ingested by the larvae during their development (Wheeler 1986; Hartfelder et al. 2006).

The larvae destined to become queens eat an increased amount of food compared to those who will develop into workers (Kerr 1948; Hartfelder \& Engels 1989; Engels \& Imperatriz-Fonseca 1990; Hartfelder et al. 2006) with the exception of bees from the genus Melipona, where the process is also associated with genetic factors (Kerr 1950; Kerr \& Laidlaw 1956; Kerr $\&$ Nielsen 1966), and few species that produce miniature queens such as Schwarzianaquadripunctata (Camargo 1974; Imperatriz-Fonseca \& Darakjian 1993; Wenseleers et al. 2005), Plebeia julianii (Juliani 1962), Plebeia remota (Ribeiro et al. 2006), Nannotrigona testaceicornis (Imperatriz-Fonseca et al. 1997) and Plebeia lucii (Teixeira \& Campos 2005).

Among the species of the genera Leurotrigona and Frieseomelitta, as well as in Plebeia lucii, the brood cells are not grouped and there is no construction 
of typical royal cells (which are notably larger); the queens develop in cells formed from the junction of two equally sized brood cells, and the adjacent cell contains only the larval food (Terada 1974; Faustino et al. 2002; Teixeira \& Campos 2005).

With the advance of meliponiculture (Cortopassi-Laurino et al. 2006), the growing interest in using these bees as agricultural pollinators, as well as the commercialization of stingless bee products, such as pollen, honey, and propolis, the demand for colonies has considerably increased.

With this in mind, we attempt to develop a technique for queen production in the laboratory as a first step to enable the production of the colonies on a large scale, allowing for their use both ecologically and economically, and to enable further study of the biology and caste determination of the stingless bees.

\section{METHODS}

The technique for "in vitro" production of stingless bee queens consists of three steps:

\section{Determination of the amount of larval food needed for the development of queens}

The biological material was taken from three colonies of Frieseomelitta varia (Lepeletier, 1836), kept at the Meliponary of the Genetic Department of the University ofSão Paulo, Ribeirão Preto, Brazil. From May 2007 to April 2008 , recently capped brood cells containing eggs $(n=522)$ were collected. The eggs were removed in the laboratory and the food in each cell was collected and volumetrically measured with a micropipette $(10 \mu \mathrm{L})$.

\section{Collection and storage of larval food}

The larval food was collected from the cells of Frieseomelitta varia by vacuum suction with the aid of a vacuum pump (Fig. 1) and rapidly cooled to $4^{\circ} \mathrm{C}$. After collection, the material was stored in a freezer at $-20^{\circ} \mathrm{C}$ for later use in larvae transference tests.

\section{Transference of the larvae}

Elisa-type 96 well $500 \mu \mathrm{L}$ round bottom acrylic plates were used in this step. Different volumes of stored larval food $(25,30,35$, 40 e $50 \mu \mathrm{L})$ were homogenized and transferred to the culture plate wells with a $50 \mu \mathrm{L}$ micropipette. 


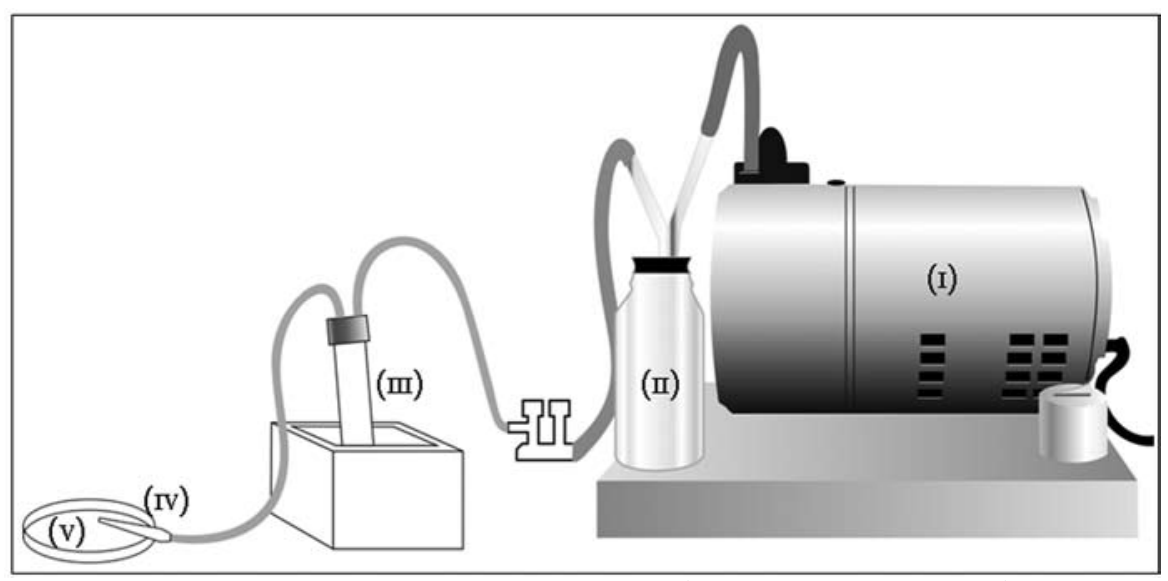

Fig. 1. Instrument used to collect larval food by suction: (I) vacuum suction pump; (II) receptacle for the collection of waste; (III) food collector tube kept in ice; (IV) food suction hose and (V) petri dish to accommodate the brood cells.
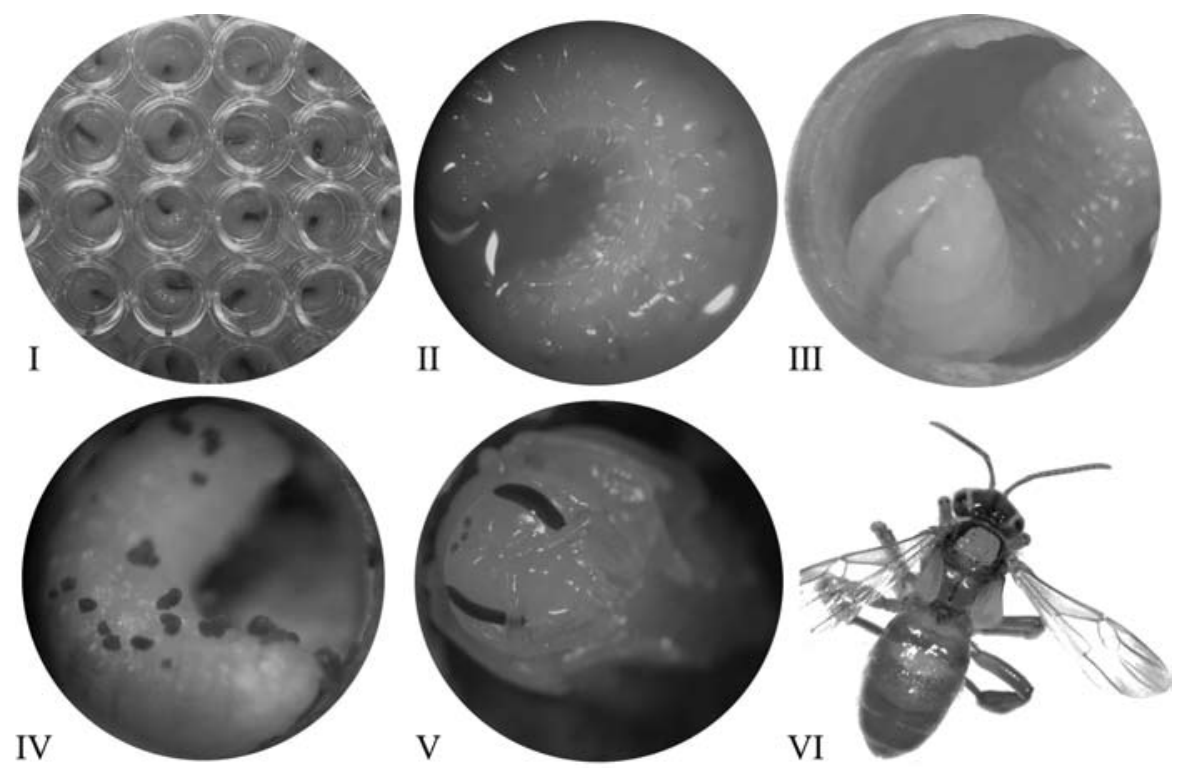

Fig. 2. (I) Larvae of Frieseomelitta varia transferred to artificial cells (Elisa-type acrylic plate). Immature developmental stages in vitro: (II) feeding larva; (III) final feeding phase; (IV) defecation phase, (V) queen pupa phase and (IV) queen. 
Larvae (immature) in the final stage of larval feeding (predefecant) with milky white coloration and a full gut were selected for this step. Using round tip tweezers, the larvae were transferred to the cells and deposited in the same position onto the larval food. At that stage of development, the Frieseomelitta varia larvae are easily identified because of their milky-white coloration, their food-filled gut and their larger size, which facilitated handling them during the transfer process.

Afterwards, the plates with the larvae were placed inside plastic containers with saturated $\mathrm{NaCl}$ solution in order to keep the humidity between $70-80 \%$ and sealed with PVC film. They were kept in BOD greenhouse at $28 \pm 1 / 2{ }^{\circ} \mathrm{C}$ and the bees' development was observed until birth (Fig. 2).

When the virgin queens emerged, they were weighed with an electronic analytical balance Metter ${ }^{\circ}$ (AE50) and then compared with the recently emerged virgin queens produced naturally in the colony.

In order to verify the dominant behavior of the in vitro produced queens, small orphaned colonies (without queen) were formed with brood combs containing imagines, 40 newly emerged workers, pollen reserves from the species itself and a $50 \%(p / v)$ sucrose solution. The queens were individually introduced to those nests, which were then covered with a transparent glass to allow for observation.

The data was analyzed using the statistical test One-way ANOVA and the Tukey test a posteriori.

\section{RESULTS}

\section{Quantifying the amount of larval food in the brood cells of Frieseomelitta varia}

We observed seasonal environmental variations with significant effect on the amount of food deposited in the brood cells (Table 1, Fig. 3, ANOVA test $\mathrm{p}<0.001$ ), during the months of larval food collection in Frieseomelitta varia. The amount of larval food in the brood cells of $F$. varia ranged from 20 to $38 \mu \mathrm{L}$ (Fig. 3).

Analyzing the total number of uncapped cells and the total volume of food collected during this time (Table 1), we observed that the average amount of larval food in a worker cell of $F$. varia is $26.7 \pm 3.55 \mu \mathrm{L}(\mathrm{n}=522)$, which varied during the year according either to the higher precipitation periods 
(February, April, May, November) or to the lower precipitation periods (June and August) (Fig. 3).

\section{In vitro production of queens}

A total of 98 queens of Frieseomelitta varia were reared using the methodology developed for in vitro production of stingless bee queens (Table 2).

After analysis of the weight of individuals produced in vitro $(\mathrm{n}=98)$ and the naturally produces queens in the colonies of $F$. varia $(n=6)$, we observed that the queens produced in vitro weighed less than those produced naturally $(\mathrm{p}<0.001)$ (Fig. 4).

Table 1: Average amount $(\mu \mathrm{L})$ of larval food from Frieseomelitta varia deposited in the brood cells during the collection months (2007-2008). SD = Standard Deviation, SEM = Standard Error of the Mean.

\begin{tabular}{llllll}
\hline \hline \multicolumn{5}{c}{ Amount of larval food in brood cells of Frieseomelitta varia } \\
\hline $\begin{array}{l}\text { Month of } \\
\text { data collection }\end{array}$ & $\begin{array}{l}\text { Total no. } \\
\text { of cells }\end{array}$ & $\begin{array}{l}\text { Total } \\
\text { volume }(\mu \mathrm{L})\end{array}$ & Mean/cell & SD & SEM \\
\hline February & 115 & 2751 & 23.92 & 2.53 & 0.24 \\
April & 64 & 1476 & 23.06 & 3.11 & 0.39 \\
May & 112 & 2713 & 24.22 & 4.78 & 0.45 \\
June & 92 & 2564 & 27.87 & 4.37 & 0.46 \\
August & 63 & 2024 & 32.13 & 3.42 & 0.43 \\
November & 76 & 2202 & 28.97 & 2.72 & 0.31 \\
Total & 522 & 13730 & 26.70 & 3.49 & \\
\hline \hline
\end{tabular}

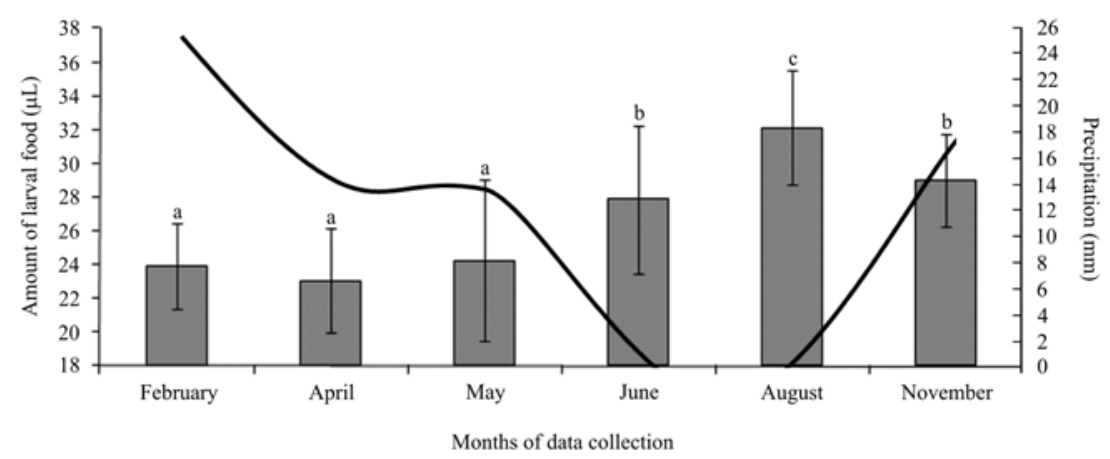

Fig. 3. Variation of the amount of larval food $(\mu \mathrm{L})$ in brood cells of Frieseomelitta varia $(\mathrm{n}=522$ cells), during the collection months (2007-2008) and the relation with precipitation (mm). Tukey's Test $(p<0,050)$. Different letters indicate statistically significant differences among months. 
The in vitro queens that were accepted by the workers in the new colonies, therefore assuming their role as dominant females $(n=11)$, had a similar weight compared to the natural queens $(n=6)$, without significant differences amoung them $(\mathrm{p}=0.083)$. The same did not occur in the other in vitro queens

Table 2: Transference of Frieseomelitta varia larvae to the in vitro production of queens with different amounts of larval food $(\mu \mathrm{L})$ and their respective survival rates (\%).

\begin{tabular}{lllllllll}
\hline \hline \multirow{2}{*}{ Test } & \multirow{2}{*}{$\begin{array}{l}\text { Volume of } \\
\text { larval food }(\mu \mathrm{L})\end{array}$} & $\begin{array}{l}\text { Transferred } \\
\text { Larvae }\end{array}$ & \multicolumn{2}{c}{ Birth rate } & \multicolumn{2}{c}{ Queens } & \multicolumn{2}{c}{ Workers } \\
\cline { 4 - 9 } & & & Number & $\%$ & Number & $\%$ & Number & $\%$ \\
\hline 1 & 25 & 100 & 82 & 82 & 13 & 16 & 69 & 84 \\
2 & 30 & 100 & 20 & 20 & 15 & 75 & 5 & 25 \\
3 & 35 & 100 & 31 & 31 & 30 & 97 & 1 & 3 \\
4 & 40 & 100 & 50 & 50 & 40 & 80 & 10 & 20 \\
5 & 50 & 100 & 0 & 0 & 0 & 0 & 0 & 0 \\
Total & 500 & 183 & 37 & 98 & 54 & 85 & 46 \\
\hline \hline
\end{tabular}

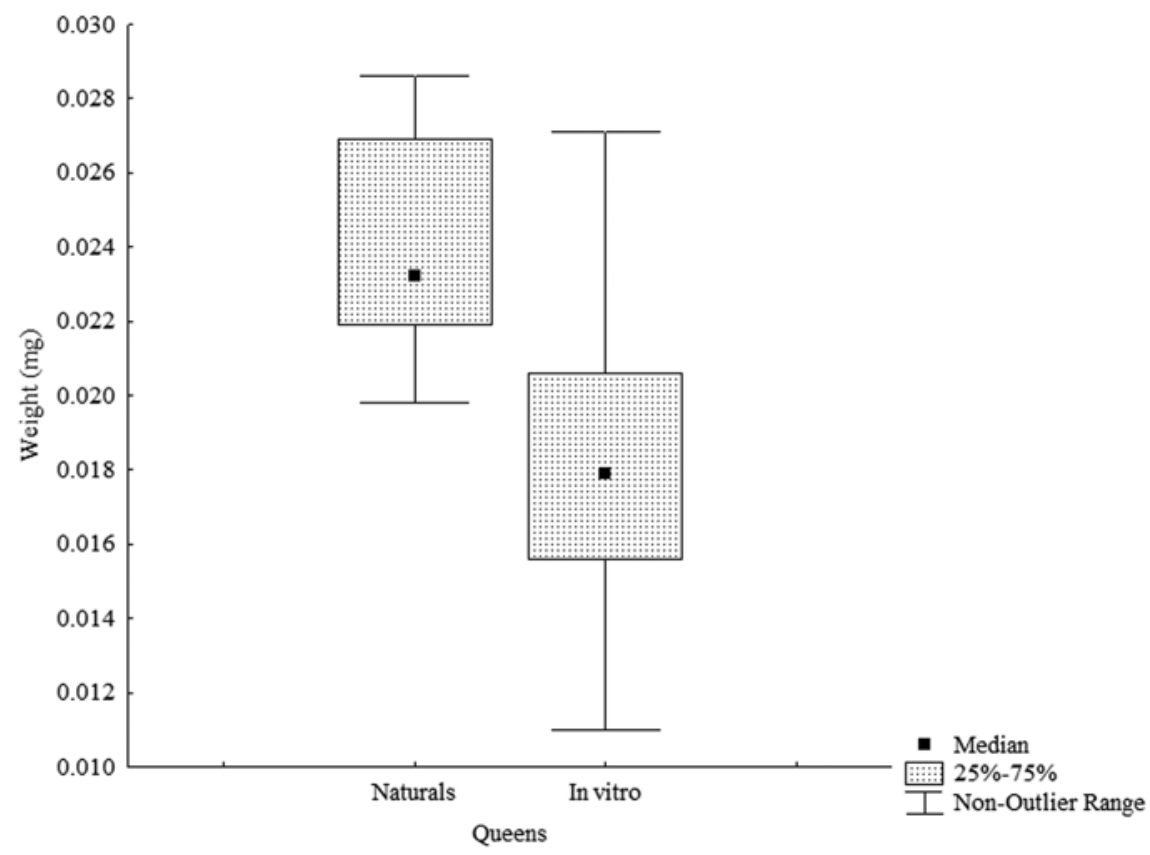

Fig. 4. Comparison of the weight $(\mathrm{mg})$ of the virgin queens of Frieseomelitta varia produced under natural conditions $(\mathrm{n}=6)$ and in vitro $(\mathrm{n}=98)$. 
$(n=87)$ that were rejected and therefore eliminated by the workers. They had a significantly lower weight than the others $(\mathrm{p}<0.001)($ Fig.5).

\section{DISCUSSION}

\section{Amount of larval food in worker cells}

An average total volume of $26.7 \pm 3.55 \mu \mathrm{L}(\mathrm{n}=522)$ (Table 1$)$ of larval food was found in the brood cells of $F$. varia. Considering that the larvae which become queens feed on the contents of their cell and on the larval food of the auxiliary cell, the larvae that become queens ingest more food than the worker larvae (Faustino et al. 2002). This results in an approximate 2:1 proportion of food, for queen larvae compared to worker larvae.

Compared with other species of Meliponini, such as Scaptotrigona aff. depilis, where the proportion of food is $4: 1(130 \mu \mathrm{L}$ in royal cells and $31 \mu \mathrm{L}$ in worker cells) (Menezes 2010), we noted that there is not a great difference in the amount of food offered to the larvae in Frieseomelitta varia; there is a

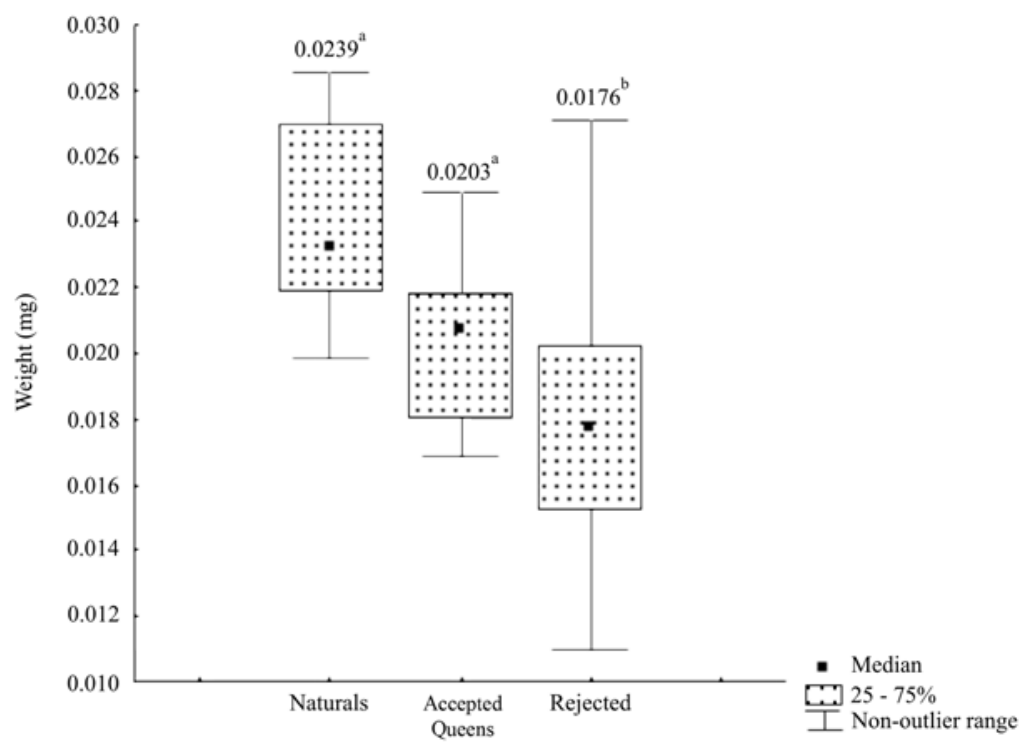

Fig. 5. Comparison between the weight ( $\mathrm{mg}$ ) of queens of Frieseomelitta varia produced under natural conditions $(\mathrm{n}=6)$ and in vitro that were accepted by the workers $(\mathrm{n}=11)$, and queens produced in vitro that were rejected and eliminated by the workers $(\mathrm{n}=87)$. ${ }^{a}$ There is no significant difference between the queens' weight $(p=0,083),{ }^{\mathbf{b}}$ there is a significant difference between the queens' weight $(\mathrm{p}<0,001)$. 
threshold for the amount of larval food responsible for differentiating a worker larva into a queen. This shows up as differences in weight, size of adults and phenotipic characteristics of queens, which are not much larger than their workers, when compared to the other species.

We verified the occurrence of a variation of the amount of larval food inside the brood cells during the collection months (February, April, May, June, August, November) coinciding with the dry and the rainy seasons of the year when there is little or much food respectively available in the environment. This occurrence was also described by Castilho-Hyodo(2001) in Schwarziana quadripunctata brood cells, where the amount of larval food was not the same year-round, but varied depending on the environmental conditions.

We attribute the variation in the amount of food in the brood cells to the availability of food resources in the environment, to the food stored in the colony, and also to the number of individuals in the colonies which is directly related to the number of active foragers. Thus, the higher the number of workers collecting food in the field, the higher the amount of food being brought into the colonies, therefore promoting an increase in the number of cells built and eventually increasing the number of individuals in the colony.

On the other hand, when there are fewer resources available, the production of brood in the colony also decreases (fewer cells are built). Consequently, the nurse workers of Frieseomelitta varia feed the larvae and deposit larger amounts of larval food per cell in order to meet the needs of the colony.

The phenomenon of a decrease in the number of brood cells and amount of larval food in each cell during times of "environmental stress" has been shown in four species of stingless bees: Melipona quadrifasciata (Ramalho et al. 1998), S. quadripunctata (Castilho-Hyodo 2001), Plebeia remota (Ribeiro et al. 2003), Scaptotrigona aff. depilis (Menezes 2010) and now in Frieseomellita varia.

This data indicates that this phenomenon is common in Meliponini species, strengthening the importance and the relation of the larval food with the mechanisms of caste determination in stingless bees, with the environmental conditions as a promoting factor of intra and extra-nesting cycles, with the production of sexed individuals (queens and males) and with the ecological expansion of those bees. 


\section{Transfer of the larvae to the production of in vitro queens}

Assuming that the larvae used in these experiments had ingested the average amount of $25 \mu \mathrm{L}$ of larval food prior to the transfer, we verified that after the consumption of extra food $(25,30,35$ e $40 \mu \mathrm{L})$, the larvae differentiated into queens.

Therefore, the total amount of food needed for the differentiation of a young larva of Frieseomelitta varia into a queen is approximately $61.70 \pm 5.00$ $\mu \mathrm{L}$, that is, the larva destined to become a queen consumes 2.31 times more food than a larva destined to become a worker. This threshold is the amount of food capable of inducing the differentiation and the morphogenetic changes in these larvae to become queens.

We found that $100 \%$ of the larvae that received $50 \mu \mathrm{L}$ of extra larval food were not able to consume it and drowned inside the food. In this way, an excess amount of larval food, around $75 \mu \mathrm{L}$, exceeds the capacity of ingestion/ digestion by the developing larvae.

These results confirm that in Frieseomelitta varia the mechanism of caste determination depends exclusively on the amount of food provided to the developing larvae and that the larvae at the end of the feeding phase (predefecant) are able to keep feeding and to develop into queens; they are still conditioned to the availability of larval food and to the ability of ingestion. These findings agree with other studies related to the effect of larval nutrition on the caste determination in stingless bees (Hartfelder et al. 2006).

The variation in the amount of food provided to the larvae which become queens also varies by species of Meliponini. In Trigona spinipes, for instance, the queens consume 10 times more food $(360 \mu \mathrm{L})$ than the workers $(36 \mu \mathrm{L})$ (Buschini \& Campos 1995; Lisboa et al. 2005); in Scaptotrigona postica, Camargo (1972) demonstrated that extra supply of food to the worker larvae caused them to develop into queens.

Another discussed factor related to the amount of food in the brood cells of Meliponini is the existence of dwarf queens that can emerge from worker cells if they receive an increased amount of food than that received by normal workers, as was noted by Campos \& Costa (1989) and Castilho-Hyodo (2001) in Schwarziana quadripunctata.

The weight of emerged individuals does not seem to influence the final acceptance or rejection, once the produced queens were accepted as dominant 
females in the new nests $(n=11)$ they had a similar weight compared to the queens produced in vitro that were eliminated by workers $(\mathrm{n}=87)$. Most likely, this suggests that the workers do not interpret queen weight as an indication of fitness, a fact that is also evident in other behavioral and physiological features (Hartfelder et al. 2006).

On the other hand, in species of stingless bees in which the phenomena of miniature queens does occur such as Nannotrigona testaceicornis, ImperatrizFonseca et al. (1997) showed that recently emerged miniature queens weighed $7.67 \mathrm{mg}$ (SD 0.87) on average, and workers weighed $7.13 \mathrm{mg}$ (SD 0.7).

There may be other intrinsic factors related to the dominant behavior (Imperatriz-Fonseca \& Zucchi 1995; Jarau et al. 2009; Jarau et al. 2010) such as patterns of cuticular hydrocarbons present in these bees (Nunes et al. 2008) which interfere with the recognition of the individuals and are related to the process of acceptance of a new queen into the nest (Nunes et al.2009) or even group decision making regarding the choice of a new queen (Tarpy \& Gilley 2004).

This method developed for the in vitro production of stingless bees was shown to be efficient, with a success rate of $45.75 \%$ ( $n=183$, excluding the values of test 5 ). We believe that one of the factors responsible for the larvae's high mortality of $54.25 \%(n=217)$ is related to the variation of the relative humidity during the first experiments. Additionally, in some cases there was an excessive amount of microorganisms in the larval food that was responsible for larval death.

Another important factor regarding the transferring oflarvae is the positioning of the larva inside the cell which can be responsible for larval mortality. One must carefully place the larva on top of the food in the same position it was found so that the larva can perform the gas exchange through the tegument when it is in contact with the air, thus avoiding its suffocation.

Eleven new colonies were obtained from the queens produced in vitro, allowing a fast increase of the number of colonies over a short period of time, demonstrating the efficiency of this technique.

In this way, our methodology can be successfully applied as a tool in studies on the mechanism of caste determination, especially those involving the large-scale production of queens from many species of stingless bees. This will allow for the production of colonies which can be used for the economic 
benefits of pollination and will also help in the conservation and reintroduction of stingless bees in their natural ecosystems.

\section{ACKNOWLEDGEMENTS}

The authors would like to thank Jairo de Souza for helping with the colony management, Ivan de Castro for the preparation of the figures, Juliana Ramos Martins for valuable comments and collaboration in the final work, Michael A. T. Freiberg (The Pennsylvania State University) for his helpful review of the text and "Centro Integrado de Informações Agrometeorológicas" of São Paulo state for the climatic data. We also thank FAPESP ( $\left.n^{\circ} 04 / 15801-0\right)$, CNPq and CAPES for supporting this work.

\section{REFERENCES}

Buschini, M.L.T. \& L.A.O. Campos 1995. Caste determination in Trigona spinipes (Hymenoptera, Apidae): influence of the available food and the juvenile hormone. Revista Brasileira de Biologia 55: 121 - 129.

Camargo, C.A. 1972. Determinaçãode castasem Scaptotrigonapostica Latreille (Hymenoptera, Apidae). Revista Brasileira de Biologia 32 (1): 133-138.

Camargo, J.M.F. 1974. Notas sobre a morfologia e biologia de Plebeia (Schwarziana) quadripunctata (Hymenoptera, Apidae: Meliponinae). Studia Entomologica 17 (1): 433-470.

Campos, L.A.O. \& M.A. Costa 1989. Determinação do sexo em abelhas: XXVIII Determinação das castas em Schwarziana quadripunctata (Hymenoptera, Apidae). Revista Brasileira de Biologia 49: 999-1001.

Castilho-Hyodo, V.C.C. 2001. Rainha ou operária? Um ensaio sobre a determinação de castas em Schwarziana quadripunctata (Lepeletier, 1836) (Hymenoptera, Apidae, Meliponini). PhD Thesis University of São Paulo, São Paulo, Brazil: 134 p.

Corlett, R.T. 2004. Flower visitors and pollination in the Oriental (Indomalayan) region. Biological Reviews 79: 497-532.

Cortopassi-Laurino, M., V.L. Imperatriz-Fonseca, D. Roubik, A. Dollin, T.Heard, I. Aguilar, G. Venturieri, C. Eardley \& P. Nogueira-Neto 2006. Global meliponiculture: challenges and opportunities. Apidologie 37:275-292.

Engels, W. \& V.L. Imperatriz-Fonseca 1990. Caste development, reproductive strategies and control of fertility in honey bees and stingless bees. In: Engels, W. (ed.) Social Insects: Springer-Verlag, Berlin, Germany: 167-230.

Faustino, C.D., E.V. Silva-Matos, S. Mateus \& R. Zucchi 2002. First record of emergency queen rearing in stingless bees. Insectes Sociaux 49: 111-113.

Hartfelder, K. \& W. Engels 1989. The composition of larval food in stingless bees: Evaluating nutritional balance by chemosystematic methods. Insectes Sociaux 36: 1-14. 
Hartfelder, K., G.R. Makert, C.C. Judice, A.G.G. Pereira, W.C. Santana, R. Dallacqua \& M.M.G. Bitondi 2006. Physiological and genetic mechanisms underlying caste development, reproduction and division of labor in stingless bees. Apidologie 37: 144-163.

Imperatriz-Fonseca, V.L. \& P. Darakjian 1993. Notas sobre o comportamento das rainhas virgens de Schwarziana quadripunctata (Apidae, Meliponinae). Ciência e Cultura 45: 912.

Imperatriz-Fonseca, V.L. \& R. Zucchi 1995. Virgin queens in stingless bees (Apidae, Meliponinae) colonies: a review. Apidologie 26: 231-244.

Imperatriz-Fonseca, V.L., C. Cruz-Landim \& R.L.M.S. Moraes 1997. Dwarf gynes in Nannotrigonatestaceicornis (Apidae, Meliponinae, Trigonini), behaviour, exocrine gland morphology and reproductive status. Apidologie 28: 113-122.

Jarau, S., J.W. van Veen, I. Aguilar \& M. Ayasse 2009. Virgin queen execution in the stingless bee Melipona beecheii: the sign stimulus forworker attacks. Apidologie 40: 496-507.

Jarau, S., J.W. van Veen, I. Aguilar \& M. Ayasse 2010. A scientific note on virgin queen acceptance in stingless bees: evidence for the importance of queen aggression. Apidologie 41 (1): 38-39.

Juliani,L.O. 1962. Aprisionamento de rainhas virgens em colônias de Trigonini(Hymenoptera, Apoidea). Boletim da Universidade do Paraná 20 (6): 1-11.

Kerr, W.E. \& H. Laidlaw 1956. General genetics of bees. Advances in Genetics 8: 109153.

Kerr, W.E. \& R.A. Nielsen 1966. Evidences that genetically determined Melipona queens can become workers. Genetics 54: 859-866.

Kerr, W.E. 1948. Estudos sobre o gênero Melipona. In: Anais Escola Superior de Agricultura "Luiz de Queiroz", Piracicaba, Brazil 5 (88): 181-276.

Kerr, W.E. 1950. Genetic determination of castes in the genus Melipona. Genetics 35: 143-152.

Kerr, W.E., G.A. Carvalho \& V.A. Nascimento 1996. Abelha uruçu: biologia, manejo e conservação. Fundação Acangaú, Belo Horizonte, Brazil: 144 p.

Lisboa, L.C.O., J.E. Serrão, C. Cruz-Landim \& L.A.O. Campos 2005. Effect of larval food amount on ovariole development in queens of Trigonaspinipes (Hymenoptera, Apinae). Anatomia Histologia Embryologia (Berlin) 34: 179-184.

Maciel-Silva, V.L. \& W.E. Kerr 1991. Sex determination in bees. XXVII. Castes obtained from larvae fed homogenized food in Melipona compressipes (Hymenoptera, Apidae). Apidologie 22 (1): 15-19.

Menezes, C. 2010. A produção de rainhas e a multiplicação de colônias em Scaptotrigona aff. depilis (Hymenoptera, Apidae, Meliponini). PhD Thesis University of São Paulo, Ribeirão Preto, Brazil: 97 p.

Michener, C.D. 2000. The bees of the world. The Johns Hopkins University Press, Baltimore, London: 913 p.

Nogueira-Neto, P. 1997. Vida e criação de abelhas indígenas sem ferrão. Nogueirapis, São Paulo, Brazil: 446 p. 
Nunes, T.M., F.S. Nascimento, I.C. Turatti, N.P. Lopes \& R. Zucchi 2008. Nestmate recognition in a stingless bee: does the similarity of chemical cues determine guard acceptance? Animal Behaviour 75: 1165-1171.

Nunes, T.M., I.C. Turatti, N.P. Lopes \& R. Zucchi 2009. Chemical signals in the stingless bee Frieseomelitta varia, indicate caste, gender, age, and reproductive status. Journal of Chemical Ecology 35: 1172-1180.

Ramalho, M., V.L.Imperatriz-Fonseca \& T.C. Giannini 1998. Within-colony sizevariation of foragers and pollen load capacity in the stingless bee Melipona quadrifasciata anthidioides Lepeletier (Apidae, Hymenoptera). Apidologie 29: 221-228.

Ribeiro, M.F., P.S. Santos-Filho \& V.L. Imperatriz-Fonseca 2003. Exceptional high queen production in the Brazilian stingless bee Plebeia remota. Studies on Neotropical Fauna and Environment 38 (2): 111-114.

Ribeiro, M.F., T. Wenseleers, P.S. Santos-Filho \& D.A. Alves 2006. Miniature queens in stingless bees: basic facts and evolutionary hypotheses. Apidologie 37: 191-206.

Roubik, D.W. 1989. Ecology and natural history of tropical bees. Cambridge University Press, New York: 514p.

Tarpy, D.R. \&D.C. Gilley 2004. Group decision making during queen production in colonies of highly eusocial bees. Apidologie 35 (2): 207-216.

Teixeira, L.V. \& L.A.O. Campos 2005. Produção de rainha de emergência em Plebeia lucii (Hymenoptera, Apidae, Meliponina). In: Simpósio Brasileiro de Insetos Sociais, Belo Horizonte, Brazil. CD-ROM.

Terada, Y. 1974. Contribuição ao estudo da regulação social em Leurotrigona mulleri e Frieseomelitta varia (Hymenoptera, Apidae). PhD University of São Paulo, Ribeirão Preto, Brazil: 96 p.

Wenseleers, T., F.L.W. Ratnieks, M.F. Ribeiro, D.A. Alves \& V.L. Imperatriz-Fonseca 2005. Working-class royalty: bees beat the caste system. Biology Letters 1: 125-128.

Wheeler, D.E. 1986. Developmental and physiological determinants of caste in social Hymenoptera: Evolutionary implications. American Naturalist 128 (1):13-34.

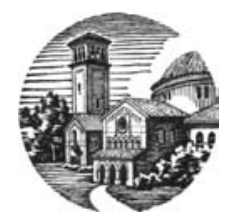

